\title{
Mantle roots of the Emeishan plume: an evaluation based on teleseismic P-wave tomography
}

\author{
Chuansong $\mathrm{He}^{1}$ and M. Santosh ${ }^{2,3}$ \\ ${ }^{1}$ Institute of Geophysics, China Earthquake Administration, Beijing 100081, China \\ ${ }^{2}$ Centre for Tectonics, Resources and Exploration, Department of Earth Sciences, University of Adelaide, \\ Adelaide, SA 5005, Australia \\ ${ }^{3}$ School of Earth Sciences and Resources, China University of Geosciences Beijing, 29 Xueyuan Road, Beijing 100083, China
}

Correspondence to: Chuansong He (hechuansong@aliyun.com)

Received: 8 February 2017 - Discussion started: 22 March 2017

Revised: 4 August 2017 - Accepted: 30 August 2017 - Published: 3 November 2017

\begin{abstract}
The voluminous magmatism associated with large igneous provinces (LIPs) is commonly correlated to upwelling plumes from the core-mantle boundary (CMB). Here we analyse seismic tomographic data from the Emeishan LIP in southwestern China. Our results reveal vestiges of delaminated crustal and/or lithospheric mantle, with an upwelling in the upper mantle beneath the Emeishan LIP rather than a plume rooted in the CMB. We suggest that the magmatism and the Emeishan LIP formation might be connected with the melting of delaminated lower crustal and/or lithospheric components which resulted in plume-like upwelling from the upper mantle or from the mantle transition zone.
\end{abstract}

\section{Introduction}

The large-scale and transient magmatic events on the globe at different times during Earth history are closely linked to mantle dynamics (Coffin and Eldholm, 2001; Ernst and Buchan, 2001). The punctuated but intense magmatic activities over the globe have generated several large igneous provinces (LIPs) in different regions (Uenzelmann-Neben, 2013; Pirajno and Hoatson, 2012). Mantle plumes which are upwellings of hot material from deeper parts of the Earth (Arndt, 2000) have been invoked to explain the link between LIPs and modern volcanoes. LIPs are characterized by large lava outpourings, such as those found in Siberia, India, and Emeishan, which also have important implications for surface environmental changes including mass extinctions (Buiter, 2014; Wignall, 2011).
Mantle upwelling received attention when Wilson (1963) suggested that the Hawaiian Islands were produced when oceanic lithosphere moved over a stationary "hot spot" in the mantle, following which the role of plumes and their relation to mantle convection was further realized (Morgan, 1971). It is now widely recognized that upwelling mantle plumes generate many LIPs (White, 2010; Safonova and Santosh, 2014). When upwelling mantle plume impinges on continental or oceanic lithosphere, large-scale eruption and intrusion of mafic and ultramafic melts occur generating LIPs (Pirajno, 2007; Shellnutt and Iizuka, 2012).

The Emeishan basalts (LIP) (ca. 257-262 Ma) in southwest China are exposed over an area of 0.25-0.3 million $\mathrm{km}^{2}$ in the Sichuan, Yunnan, and Guizhou provinces, comprising a total volume of about 0.25 million $\mathrm{km}^{3}$ (Huang and Opdyke, 1998), with the thickness of the basaltic flow ranging from 100 to $200 \mathrm{~m}$ in the eastern part to more than $5 \mathrm{~km}$ in the west (Ali et al., 2010; Deng et al., 2010). The region has been divided into three zones (inner, intermediate, and outer) (Fig. 1) based on biostratigraphic, sedimentological, and geochemical characteristics (Xu et al., 2001; Deng et al., 2010).

Previous studies suggested that the Emeishan flood basalts were generated by mantle plume impingement at the base of the lithosphere, which resulted in large-scale regional updoming prior to volcanism (Shellnutt et al., 2012; X. H. Li et al., 2002) and led to a short eruption of less than $1 \mathrm{Myr}$ (Song et al. 2004). However, some researchers (e.g. Ukstins Peate and Bryan, 2008) have also challenged the concept of upwelling mantle plume leading to LIP formation in the 


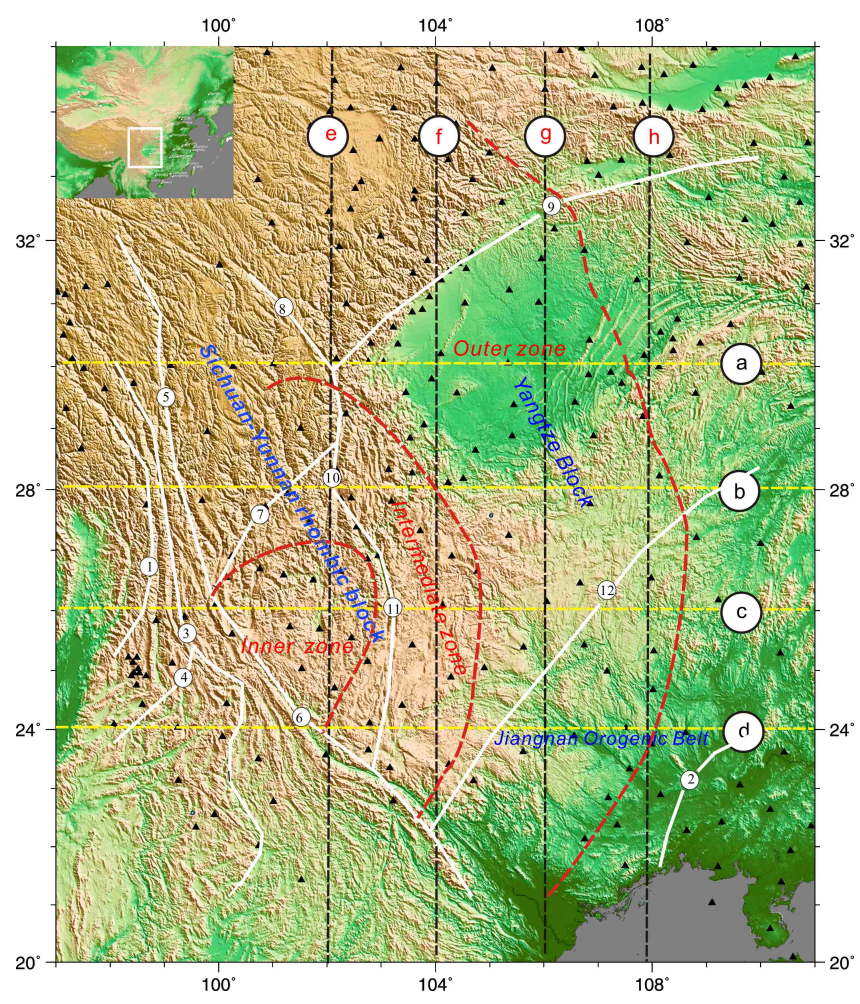

Figure 1. Tectonic framework, distribution of seismic stations (black triangle) and the east-west and north-south profiles in the Emeishan LIP area. 1: Nujiang Fault; 2: Shaoxing-JiangshanPingxiang Fault; 3: Langcangjiang Fault; 4: Nanding He Fault; 5: Weixi-Qiaohou Fault; 6: Red River fault; 7: Yangjiang-Xiaojinhe Fault; 8: Xianshui He Fault; 9: Longmen Shan Fault; 10: AnningHe-Zhemuhe Fault; 11: Xiaojiang Fault; 12: Jiujiang-Shitai buried fault.

Emeishan area. It has also been argued that submarine volcanism took place during the emplacement of the Emeishan LIP and that some lava flows close to the centre of the LIP were erupted in a submarine setting (Ukstins Peate and Bryan, 2008; Ali et al., 2010). This model considers that the products of initial eruption were extruded at around sea level and that the moderately positive topography is a reflection of the rapid accumulation of the volcanic pile (Ukstins Peate and Bryan, 2008). Thus, the Emeishan LIP formation still remains a controversial topic, and the key issue is whether there is a plume upwelling rooted in the core-mantle boundary $(\mathrm{CMB})$.

In the past 2 decades, several seismic tomographic studies have been carried out on the Emeishan LIP and surrounding regions, including 2.5-D tomography of the uppermost mantle (Lü et al., 2014), ambient noise Love and Rayleigh wave tomography ( $\mathrm{Li}$ et al., 2010, 2009), teleseismic P-wave tomography (Bai et al., 2011; Yang et al., 2014; Huang et al., 2015), local earthquake tomography (Huang et al., 2009; Xu et al., 2012), interstation $P g$ and $S g$ differential travel-time tomography (Li et al., 2014), and $P n$ anisotropic tomography
(Lei et al., 2014). These works have revealed the velocity structure of the crust and upper mantle beneath this region, although they did not directly address the mechanism of the Emeishan LIP formation.

Huang et al. (2015) carried out a tomographic study using 411 temporary stations within $20-33^{\circ} \mathrm{N}$ and $95-110^{\circ} \mathrm{E}$ and obtained the velocity structure of the crust and upper mantle in the Chuandian area. Here, we carry out an extended study in the region northward and eastward within $20-35^{\circ} \mathrm{N}$ and $97-111^{\circ} \mathrm{E}$ so as to cover all the regions of the Emeishan LIP. Our target is to construct the velocity structure beneath the Emeishan area, based on which we evaluate the geodynamics of Emeishan LIP formation.

\section{Data and method}

The basic principle for teleseismic tomography assumes that the relative travel-time residuals resulted from the heterogeneity in the model space (e.g. Yang et al., 2014; Zhao et al., 1992). The location of the seismic ray crossing through the boundary of the study region was determined by a 1-D (or 1-D IASP91) velocity model, and theoretical travel time and seismic ray paths are obtained by the fast ray tracing technique (or pseudo-bending technique) (Zhao et al., 1992). Three-dimensional grids are employed to express the velocity perturbation values, and any point in the model space can be calculated from the values of the surrounding eight nodes by pseudo-linear interpolation (Zhao et al., 1992, 1994).

We collected data recorded by the China seismic network from July 2007 to March 2014, which comprises 228 seismic stations in the study region (Fig. 1). The 371 teleseismic events were selected with epicentral distance ranging from $30^{\circ}$ to $85^{\circ}$ and corresponding to earthquake magnitude $>6.0$ (Fig. 2). P arrivals were correlated on the vertical component after bandpass filtering between 0.3 and $3 \mathrm{~Hz}$. Our assembled data set contains $42500 \mathrm{P}$-wave arrivals. We limited the relative travel-time residuals used in our tomographic inversion to between $>-2 \mathrm{~s}$ and $<+2 \mathrm{~s}$ (Fig. 3). To analyse this data set, we used the tomographic method of Zhao et al. (1994). The three-dimensional grid nodes were set up, with a lateral grid spacing of $1^{\circ} \times 1^{\circ}$ and a vertical grid spacing of 50, 100, 200, 300, 400, 500, 600, 700, and $800 \mathrm{~km}$.

In teleseismic tomography, rays do not crisscross well in the crust and the uppermost mantle beneath the study region. Therefore, the effect of crustal heterogeneity needs to be removed through correcting the relative travel-time residuals, which is called crustal correction (Jiang et al., 2009, 2015). In this work, the CRUST1.0 model (Laske et al., 2012) is used to make the crustal correction to the relative travel-time residuals following the scheme of Jiang et al. (2015). Here, we calculate the crustal correction for the upper $50 \mathrm{~km}$ of the Earth.

The velocity perturbations from the 1-D IASP91 Earth model (Kennett and Engdahl, 1991) at each grid node were 


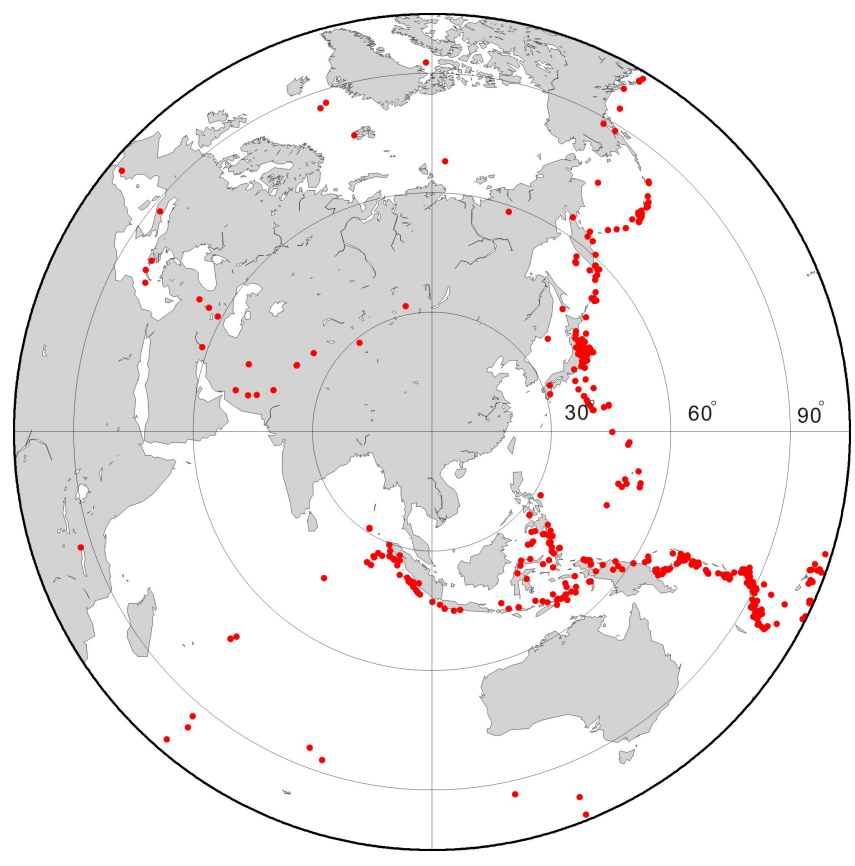

Figure 2. Seismic events used in this tomographic study. The 371 events with epicentre distance range from 30 to $85^{\circ}$ for each station-event pair.

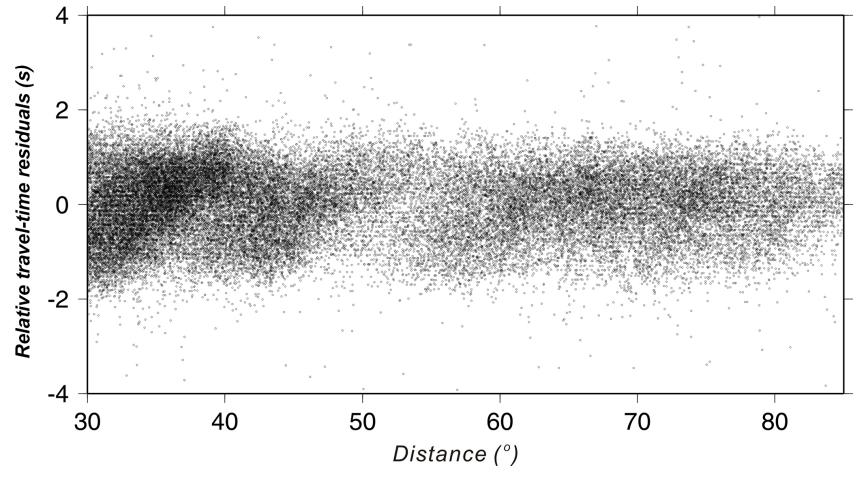

Figure 3. Distribution of relative travel-time residuals. We limited it to between $>-2 \mathrm{~s}$ and $<2 \mathrm{~s}$ for the tomographic inversion.

taken as an unknown parameter. The LSQR algorithm (Paige and Saunders, 1982) was used to solve the large and sparse system of observation equations with damping and smoothing regularizations (Zhao, 2004). The optimal value of the damping is based on the trade-off curve between the rms travel-time residuals and the norm of the model after many tests, and, eventually, 15 was adopted as the damping parameter for tomographic inversion (Fig. 4).

For evaluating the resolution of the 3-D velocity structure, we carried out checkerboard resolution tests (CRTs) (Zhao et al., 1994; Rawlinson and Spakman, 2016) and assigned positive and negative velocity perturbations of $\pm 5 \%$ to all the 3-D grid nodes. Synthetic travel times are calculated for the checkerboard model with the same station-event pairs in

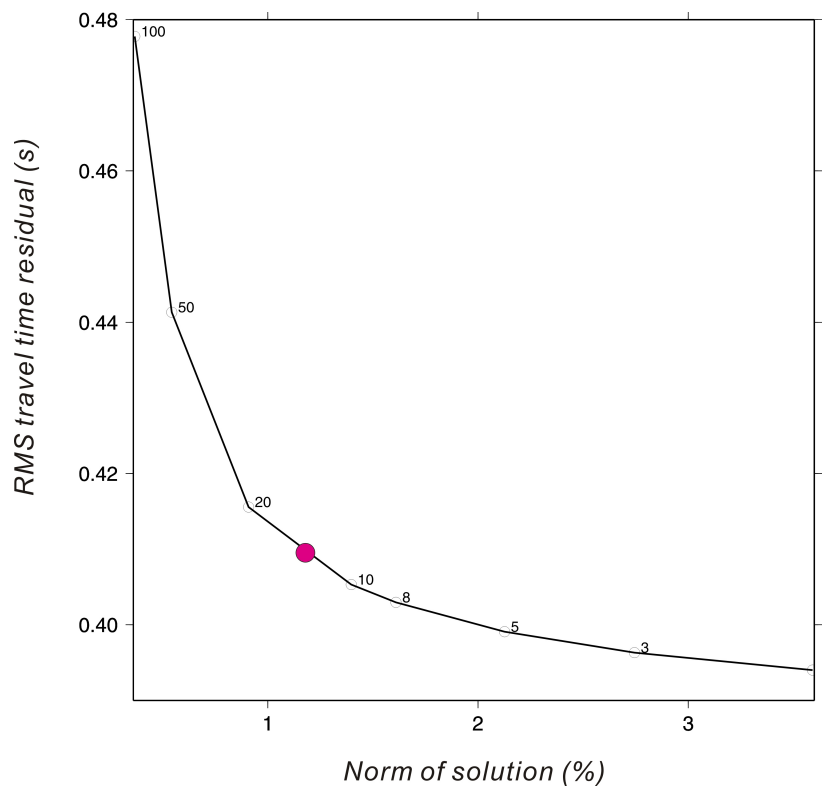

Figure 4. The damping parameter (15) taken for the final solution model (red circle) after a series of trial inversion. The rms traveltime residual is about $0.41 \mathrm{~s}$.

the synthetic data. We then inverted the synthetic data with the same algorithm as that for the observed data. Although the CRTs have a number of potential drawbacks (Rawlinson and Spakman, 2016), the results basically reflect the resolution of the tomography and are part of the technique for routine checking. The results show that the resolution is generally high in most parts of the study area (Fig. 5), except for the marginal region and 50 and $800 \mathrm{~km}$ depth sections. We also carried out the checkerboard test along west-east and north-south profiles (see Fig. 1 for profile location). The east-west profiles show high resolution for all profiles, and the synthetic data can be recovered in the main part, except for the western part of the section (Fig. 6). The north-south profiles also show high resolution in most parts, except for the marginal region (Fig. 7). The results of the checkerboard test demonstrated that our data and calculation adequately meet with the required resolution for the main area of this study.

\section{Results}

The results from this study show large-scale high-velocity perturbation (Hv1) in the 50, 100, 200, and $300 \mathrm{~km}$ depth sections in the northeastern part of the study area or Yangtze Block, which reflects the lithospheric root of the Sichuan Basin (Fig. 8). They are consistent with previous teleseismic P-wave tomographic studies (Yang et al., 2014; Huang et al., 2015; Li et al., 2006). A large-scale high-velocity perturbation (Hv2) appears in the 300 and $400 \mathrm{~km}$ depth sections in the central part (Fig. 8). Huang et al. (2015) also defined 

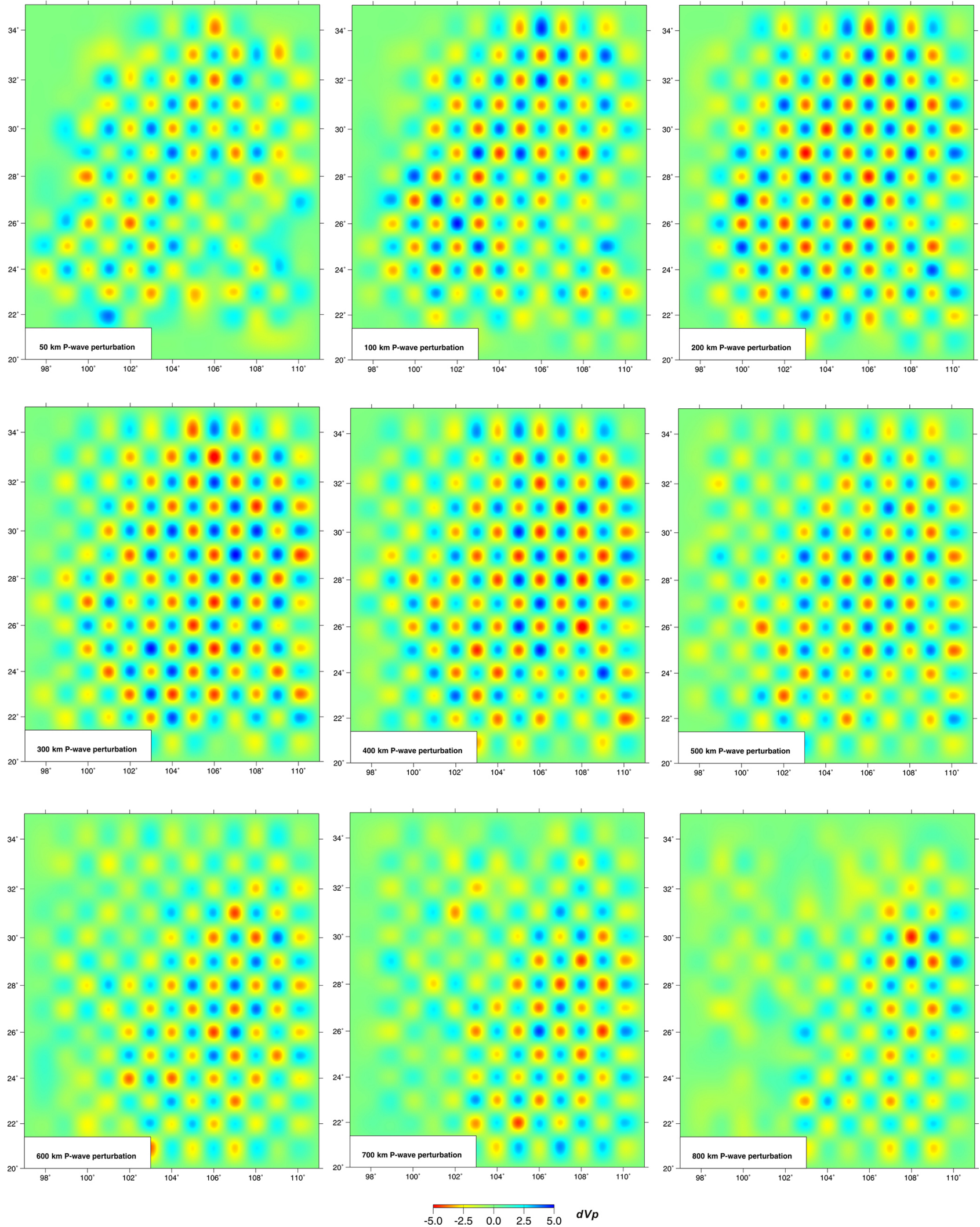

Figure 5. Checkerboard resolution test at 50, 100, 200, 300, 400, 500, 600, 700, and $800 \mathrm{~km}$ depth sections relative to the IASP91 1-D velocity model (Kennett and Engdahl, 1991). The model was run using the same stations or events as the main inversion, with the same damping parameter. 

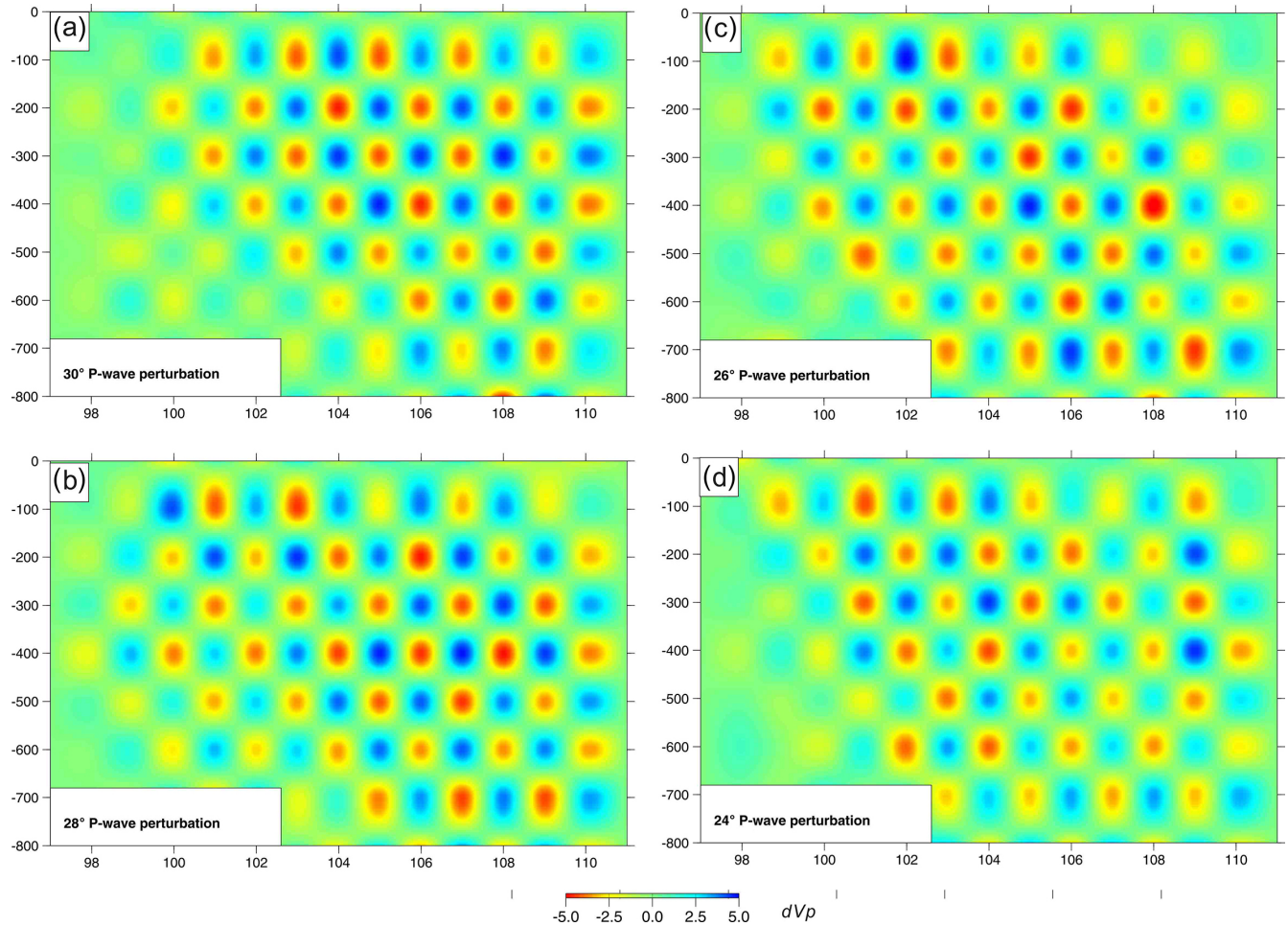

Figure 6. Checkerboard resolution test along the west-east profiles (a, b, $\mathbf{c}$, and $\mathbf{d}$ are at latitudes $24,26,28$, and $30^{\circ} \mathrm{N}$, respectively) (see Fig. 1 for profile location).
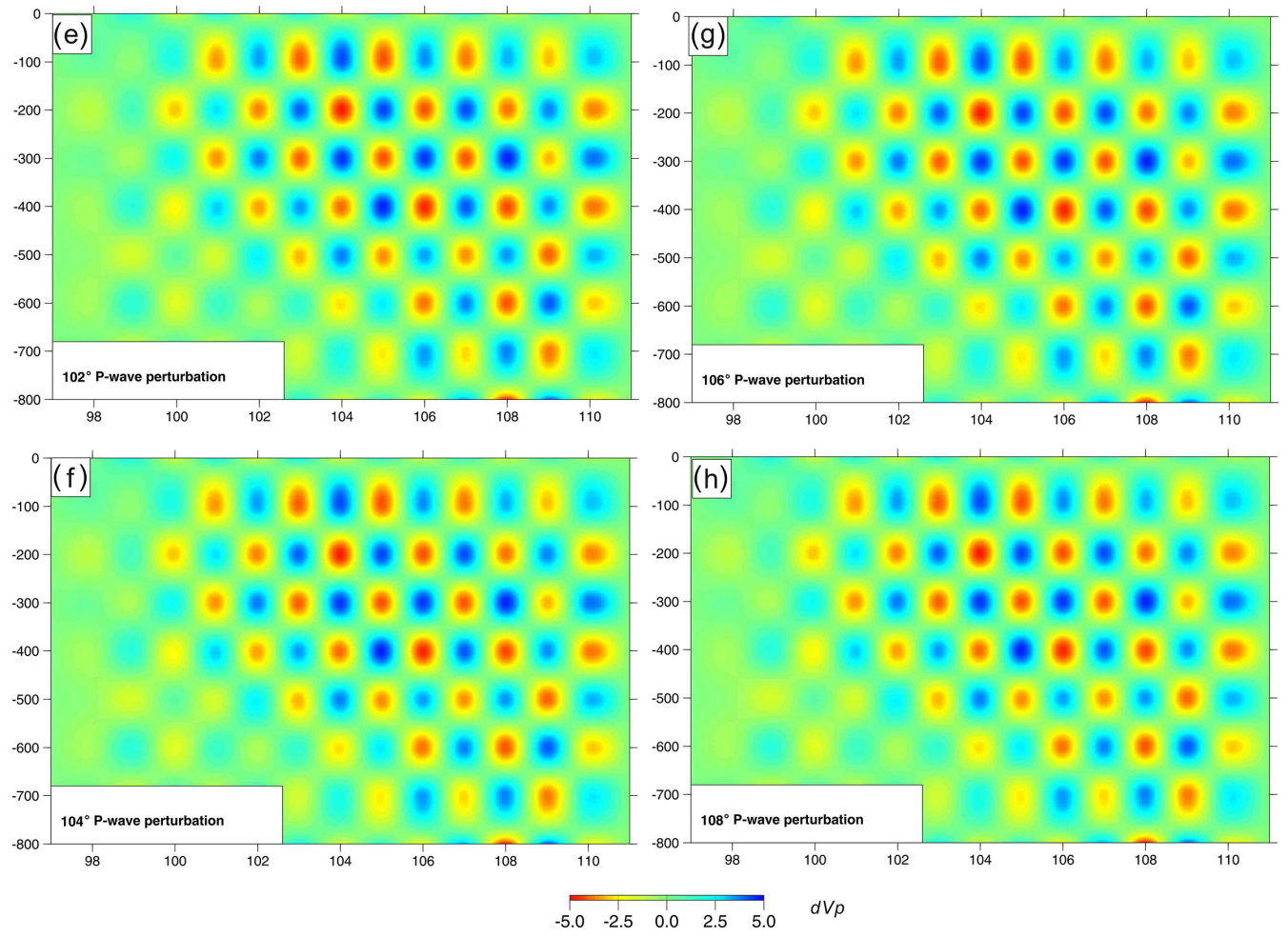

Figure 7. Checkerboard resolution test along the north-south profiles (e, f, $\mathbf{g}$, and $\mathbf{h}$ are sections along longitudes $102,104,106$, and $108^{\circ} \mathrm{E}$, respectively) (see Fig. 1 for profile location). 

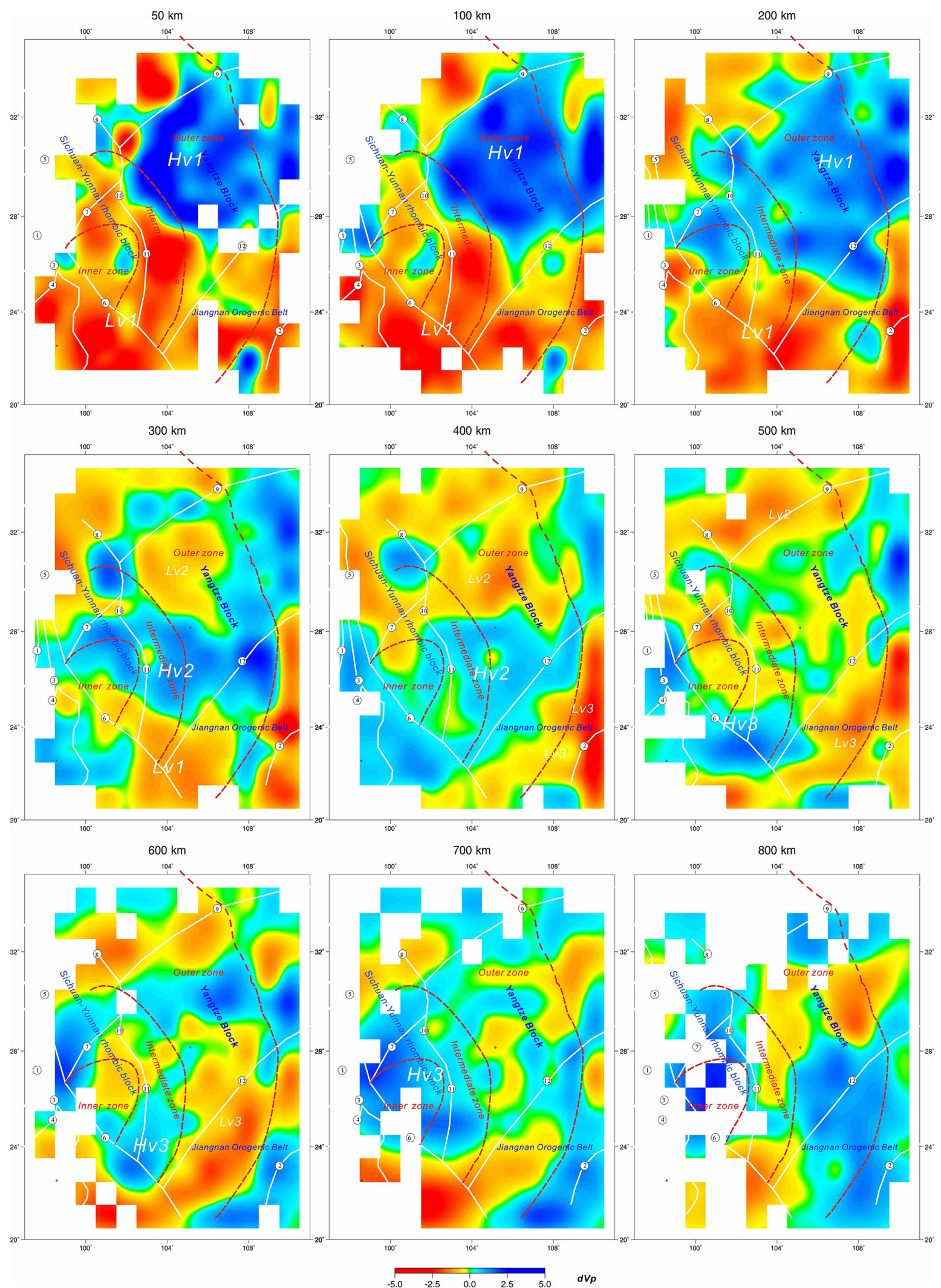

Figure 8. P-wave velocity perturbation at 50, 100, 200, 300, 400, 500, 600, 700, and $800 \mathrm{~km}$ depth sections relative to the IASP91 $1 \mathrm{D}$ velocity model (Kennett and Engdahl, 1991). Portions of the model where the recovery of the starting model in the CRT was below $20 \%$ are not shown (see Fig. 5). 
a large-scale high-velocity perturbation at 350 and $400 \mathrm{~km}$ depth. High-velocity perturbations ( $\mathrm{Hv} 3$ ) are revealed in the 500,600 , and $700 \mathrm{~km}$ depth sections (most in the mantle transition zone) (Fig. 8). In the southern part of the study area, a large-scale low-velocity perturbation (Lv1) is seen in the 50, 100, 200, and $300 \mathrm{~km}$ depth sections (Fig. 8). Huang et al. (2015) and Yang et al. (2014) also defined a lowvelocity perturbation at $100-200 \mathrm{~km}$ depth. In the 300,400 , and $500 \mathrm{~km}$ depth sections, there is a low-velocity perturbation (Lv2) in the central part of the Emeishan LIP (Fig. 8). In the 400, 500, and $600 \mathrm{~km}$ depth sections, there is an obvious low-velocity perturbation (Lv3) in the southeastern part of the region (Fig. 8).

In the east-west direction profile, the high-velocity perturbation (Hv1) or the lithospheric root of the Sichuan Basin can be clearly seen in Fig. 9a and b. The large-scale high-velocity perturbation (Hv2) occurs in the upper mantle around 26-28 (Fig. 9b, c). A high-velocity perturbation (Hv3) is seen in the MTZ (mantle transition zone; Fig. 9). In Fig. 9d, a large-scale low-velocity perturbation (Lv1) appears in the upper mantle (along the $24^{\circ} \mathrm{N}$ ). Yang et al. (2014) and Huang et al. (2015) also defined a low-velocity perturbation along $25^{\circ} \mathrm{N}$. In the 28 and $30^{\circ}$ profiles, the Lv 2 and Lv3 can be seen in the upper mantle and mantle transition zone, respectively. In the northsouth profile, the results also show Lv1 (Fig. 10e, f, and g), Lv2 (Fig. 10f, g), Lv3 (Fig. 10g, h), Hv1 (Fig. 10f, g, and h), and Hv2 (Fig. 10).

\section{Discussion}

\subsection{Location of the Emeishan LIP formation}

The south China Block docked with the Indochina Block in the southwest in the Early Triassic along the Ailao-ShanRed-River-fault Song Ma suture, in the west along the Longmen Shan Fault, and in the north with the North China Craton along the Qin-Ling-Tongbai-Hong'an-Dabie-Sulu orogenic belt (Z. Li et al., 2002; Zheng et al., 2013). The Emeishan LIP is considered to have formed in the Permian-Triassic (Song et al., 2013; Chung and Jahn, 1995). The LIP was broken up by the Red River fault (Xiao et al., 2004) and the Longmen Shan Fault (He et al., 2007). However, the $\sim 260$ Ma Emeishan LIP in SW China and northern Vietnam includes voluminous continental flood basalts that are believed to have formed from the same upwelling mantle (Chung and Jahn, 1995; Xu et al., 2004). The region was located at the western side of the Red River fault in the Early Triassic and was displaced several hundred kilometres to the southeast by Oligo-Miocene sinistral motion along the AilaoShan-Red-River fault (Ali et al., 2005). These features suggest that the Emeishan LIP was generated after the amalgamation of the south China and Indochina blocks in the Early Triassic along the Ailao-Shan-Red-River fault-Song Ma suture. Since the Early Triassic, there is no documented ev- idence to show that the location of the Emeishan LIP has changed.

On the other hand, a receiver function study revealed a felsic lower crust in the Emeishan area, suggesting crustal delamination (He et al., 2014). Simultaneously, the MTZ beneath this region shows a cold domain (He et al., 2014), which might suggest that the delaminated cold material dropped down into the MTZ. Generally, crustal delamination can induce mantle upwelling (Elkins-Tanton and Hager, 2000; Elkins-Tanton, 2005), which might have eventually resulted in a convective circulation system between the lower crust and the MTZ beneath the Emeishan area (He et al., 2014). This further confirms the present location of the Emeishan LIP.

\subsection{Mechanism of the Emeishan LIP formation}

The rise and impingement of mantle plumes on continental and oceanic lithospheric plates would lead to the formation of mafic/ultramafic lower crust (Pirajno, 2007). Some of the previous studies indicated a high-velocity lower crust beneath the Emeishan LIP (Xu et al., 2007), suggesting a mafic/ultramafic lower crust generated by lower crustal underplating or the upwelling mantle plume during the later Permian (Xu et al., 2004; Usuki et al., 2015). However, the dominantly felsic to intermediate lower crust in this area identified from receiver function analyses (He et al., 2014; Sun et al., 2012) does not favour any underplating in the Emeishan LIP area.

Alternate models consider that the LIP magmatism was triggered by decompression-induced melting of the upper mantle beneath zones of lithospheric extension or fractures (Uenzelmann-Neben, 2013), which does not require any upwelling mantle plume. Preeruptive subsidence and asthenospheric flow into voids created by the delamination of dense eclogitic lower crust and/or lithosphere have been proposed by some researchers (Anderson, 2007; Hales et al., 2005), such as in the case of the Siberian Trap basalts (ElkinsTanton and Hager, 2000).

It has been shown that in some cases, high- and lowvelocity relics generated by subducted slab or crustal and mantle lithospheric delamination resulting in the upwelling of the asthenospheric mantle can be retained for a long time, even a couple of billion years (Cook et al., 1999; Balling, 2000; Svenningsen et al., 2007; Zhai et al., 2007; He et al., 2015). These low- and high-velocity structures can be imaged by tomography (Zhao et al., 1992, 1994; Zhao et al., 2016).

The crustal and/or mantle lithospheric delamination can generate mantle upwelling and extensive volcanism (Vlaar et al., 1994; van Thienen et al., 2004). A large-scale lower crustal and/or mantle lithospheric delamination or sinking (Hv3) (Fig. 9) may stop at the $660 \mathrm{~km}$ discontinuity identified by this study, where crustal and lithospheric components would be melted (Lustrino, 2005) because the MTZ is a po- 

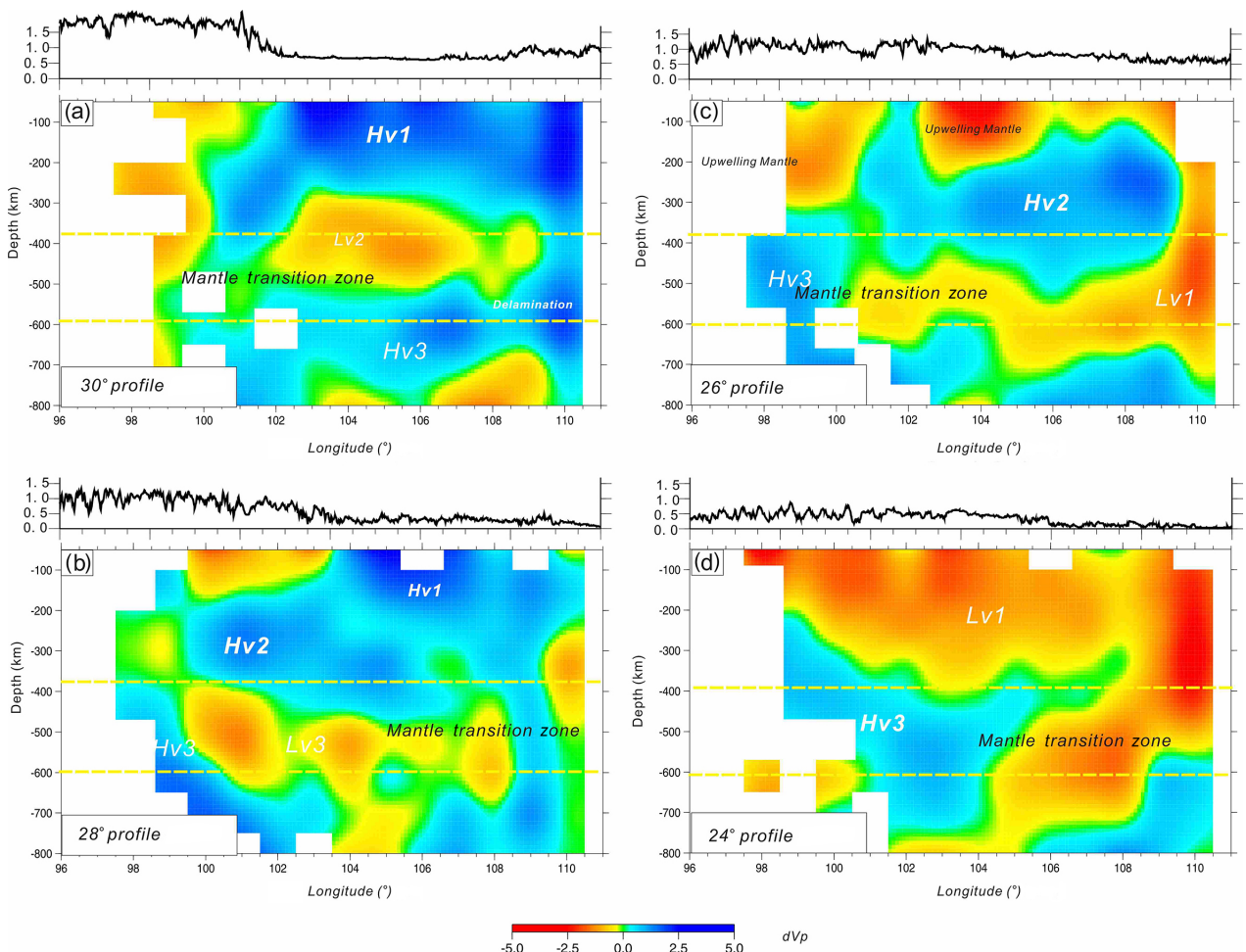

Figure 9. P-wave velocity perturbation profiles along the west-east direction (a, b, c, and $\mathbf{d}$ are at latitudes $24,26,28$, and $30^{\circ} \mathrm{N}$, respectively) (see Fig. 1 for profile location). Portions of the model where the recovery of the starting model in the CRT was below $20 \%$ are not shown (see Fig. 6).
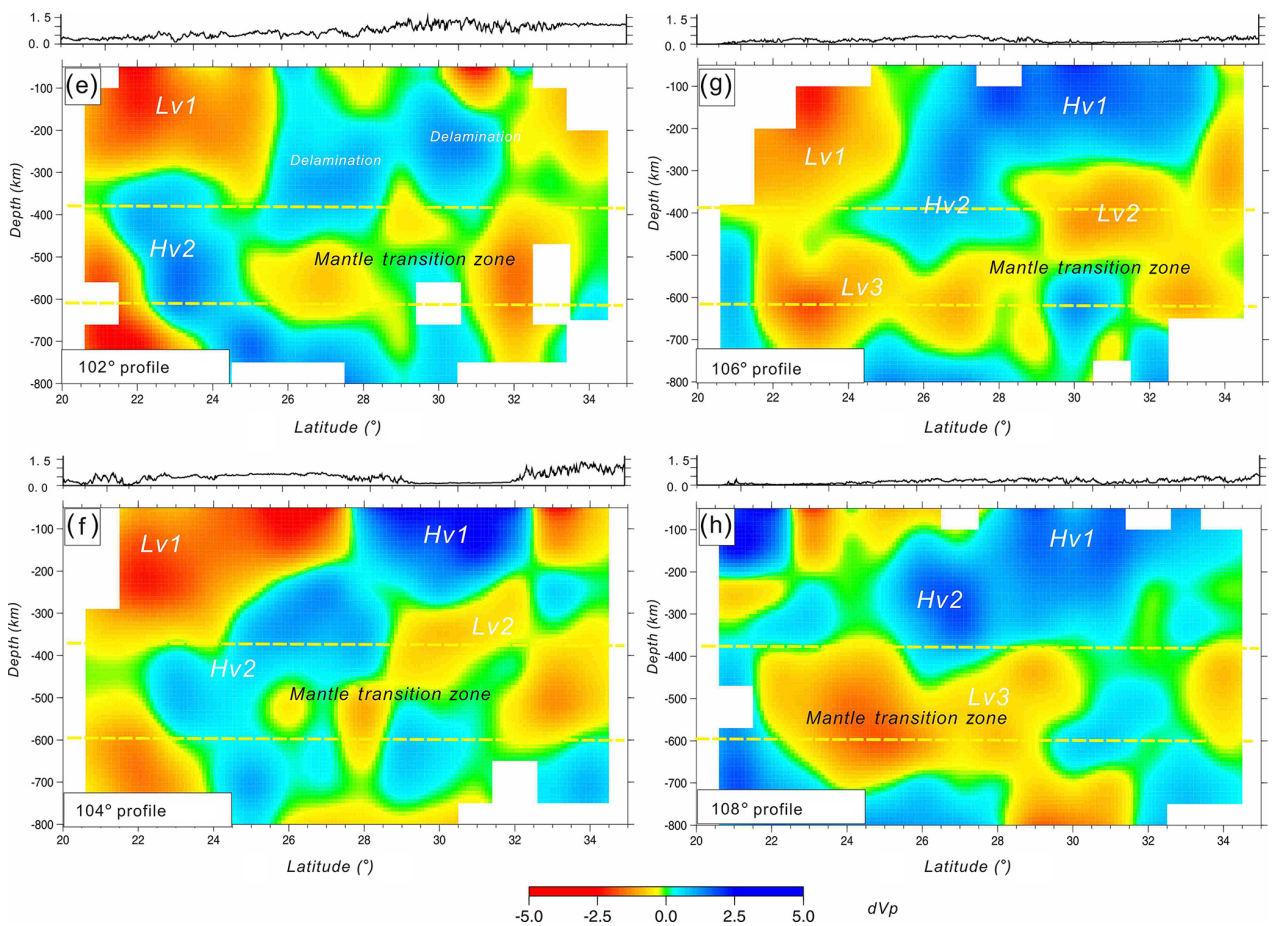

Figure 10. P-wave perturbation profiles along the north-south direction (e, f, g, and $\mathbf{h}$ are sections along longitudes 102, 104, 106, and $108^{\circ} \mathrm{E}$, respectively) (see Fig. 1 for profile location). Portions of the model where the recovery of the starting model in the CRT was below $20 \%$ are not shown (see Fig. 7). 
tential water reservoir in the Earth's interior (Karato, 2011; Kuritani et al., 2011). The accumulation of delaminated crust and/or mantle lithosphere in the MTZ are speculated to give rise to "second continents" at the bottom of the upper mantle (Kawai et al., 2013; Lustrino, 2005). The hydrous minerals in the MTZ as "water tanks" might trigger dehydration melting of vertically flowing mantle (Schmandt et al., 2014). Because of their buoyancy, crustal and/or mantle lithospheric melts rise up as plume-like upwelling instead of being dragged down to the convecting lower mantle (Lustrino, 2005). Thus, lower crustal and/or mantle lithospheric delamination and mantle inflow are considered to set the ideal scene for plumelike upwelling from the MTZ (He et al., 2014). Meanwhile, removal of the lower crust and/or mantle lithosphere (Hv2) (Fig. 10) allows the mantle to rise to shallower depths leading to decompression melting reflected as low-velocity perturbations (Elkins-Tanton and Hager, 2000; Elkins-Tanton, 2005). Therefore, we suggest that the Lv1, Lv2, and Lv3 identified in our study (Figs. 8, 9, and 10) may represent upwelling from the upper mantle or mantle transition zone generated by the delamination of the low crust and/or mantle lithosphere rather than plumes rooted in the core-mantle boundary. These upwellings might be linked to the formation of the Emeishan LIP.

\section{Conclusions}

The tectonic framework of Emeishan LIP is characterized by the Longmen Shan thrust fault in the northwest and the Ailao-Shan-Red-River strike-slip fault in the southwest. It is possible that the assembly of the Yangtze Block with another crustal block in the late Permian and Early Triassic, which is the major tectonic event in the Emeishan area, resulted in crustal thickening and large-scale delamination of the lower crust and/or mantle lithosphere. The delamination may have triggered mantle upwelling and the generation of crustal melts resulting in the Emeishan LIP formation.

Our results show that there is no low-velocity perturbation rooted in the lower mantle beneath the Emeishan LIP, suggesting the absence of any vestiges of a mantle plume rising from the $\mathrm{CMB}$ beneath the Emeishan area.

Data availability. The data are not publicly accessible due to national policy. Waveform data for this study are provided by the Data Management Centre of China National Seismic Network (2007) at the Institute of Geophysics (SEISDMC, https://doi.org/10.11998/SeisDmc/SN), the China Earthquake Networks Center, and the CQ, GX, GZ, QH, SC, XZ, YN Seismic Networks, China Earthquake Administration (Zheng et al., 2010).

Competing interests. The authors declare that they have no conflict of interest.
Acknowledgements. This study is supported by National Key R\&D Program of China (2017YFC0601406). Waveform data for this study are provided by the Data Management Centre of China National Seismic Network (2007) at the Institute of Geophysics (SEISDMC, https://doi.org/10.11998/SeisDmc/SN), the China Earthquake Networks Center, and the CQ, GX, GZ, QH, SC, XZ, YN Seismic Networks, China Earthquake Administration (Zheng et al., 2010). This study also benefits from the Foreign Expert funding from China University of Geosciences Beijing and professorial support from the University of Adelaide to M. Santosh.

Edited by: Tarje Nissen-Meyer

Reviewed by: Guust Nolet and one anonymous referee

\section{References}

Ali, J. R., Thompson, G. M., Zhou, M. F., and Song, X. Y.: Emeishan large igneous province, SW China, Lithos, 79, 475-489, 2005.

Ali, J. R., Fitton, J. G., and Herzberg, C.: Emeishan large igneous province (SW China) and the mantle-plume up-doming hypothesis, J. Geol. Soc. London, 167, 953-959, 2010.

Anderson, D. L.: The Eclogite Engine: Chemical geodynamics as a Galileo thermometer, Geol. S. Am. S., 430, 47-64, https://doi.org/10.1130/2007.2430(03), 2007.

Arndt, N.: Hot heads and cold tails, Nature, 407, 458-461, 2000.

Bai, Z. M., Tian, X. B., and Tian, Y.: Upper mantle P-wave tomography across the Longmenshan fault belt from passive-source seismic observations along Aba-Longquanshan profile, J. Asian Earth Sci., 40, 873-882, 2011.

Balling, N.: Deep seismic reflection evidence for ancient subduction and collision zones within the continental lithosphere of northwestern Europe, Tectonophysics, 329, 269-300, 2000.

Buiter, S.: How plumes help to break plates, Nature, 513, 36-37, 2014.

Chung, S. L. and Jahn, B. M.: Plume-lithosphere interaction in generation of the Emeishan flood basalts at the Permian-Triassic boundary, Geology, 23, 889-892, 1995.

Coffin, M. F. and Eldholm, O.: Large igneous provinces: progenitors of some ophiolites, in: Mantle Plumes: Their Identification through Time, edited by: Ernst, R. E. and Buchan, K. L., Geol. S. Am. S., 352, 59-70, 2001.

Cook, F. A., Velden, A., Hall, K. W., and Roberts, B.: Frozen subduction in Canadas Northwest Territories: lithoprobe deep lithospheric reflection profiling of the western Canadian Shield, Tectonics, 18, 1-24, 1999.

Data Management Centre of China National Seismic Network: Waveform data of China National Seismic Network, Institute of Geophysics, China Earthquake Administration, https://doi.org/10.11998/SeisDmc/SN, 2007.

Deng, J., Wang, Q. F., Yang, S. J., Liu, X. F., Zhang, Q. Z., Yang, L. Q., and Yang, Y. H.: Genetic relationship between the Emeishan plume and the bauxite deposits in Western Guangxi, China: Constraints from $\mathrm{U}-\mathrm{Pb}$ and $\mathrm{Lu}-\mathrm{Hf}$ isotopes of the detrital zircons in bauxite ores, J. Asian Earth Sci., 37, 412-424, 2010.

Elkins-Tanton, L. T.: Continental magmatism caused by lithospheric delamination, Geol. S. Am. S., 388, 449-461, 2005. 
Elkins-Tanton, L. T. and Hager, B. H.: Melt intrusion as a trigger for lithospheric foundering and the eruption of the Siberian flood basalts, Geophys. Res. Lett., 27, 3937-3940, 2000.

Ernst, R. E. and Buchan, K. L.: Large mafic magmatic events through time and links to mantle plume heads, Geol. S. Am. S., 352, 483-576, 2001.

Hales, T. C., Abt, D. L., Humphreys, E. D., and Roering, J. J.: A lithospheric instability origin for Columbia River flood basalts and Wallowa Mountains uplift in northeast Oregon, Nature, 438, 843-845, 2005.

He, B., Xu, Y. G., Huang, X. L., Lou, Z. Y., Shi, Y. R., Yang, Q. J., and Yu, S. Y.: Age and duration of the Emeishan flood volcanism, SW China: Geochemistry and SHRIMP zircon U-Pb dating of silicic ignimbrites, post-volcanic Xuanwei Formation and clay tuff at the Chaotian section, Earth Planet. Sc. Lett., 255, 306323, 2007

He, C. S., Santosh, M., Wu, J. P., and Chen, X. H.: Plume or no plume: Emeishan Large Igneous Province in Southwest China revisited from receiver function analysis, Phys. Earth Planet. In., 232, 72-78, 2014.

He, C. S., Santosh, M., and Dong, S. W.: Continental dynamics of Eastern China: insights from tectonic history and receiver function analysis, Earth-Sci. Rev., 145, 9-24, 2015.

Huang, K. and Opdyke, N. D.: Magnetostratigraphic investigations of an Emeishan basalt section in western Guizhou Province, China, Earth Planet. Sc. Lett., 163, 1-14, 1998.

Huang, R. Q., Wang, Z., Pei, S. P., and Wang, Y. S.: Crustal ductile flow and its contribution to tectonic stress in Southwest China, Tectonophysics, 473, 476-489, 2009.

Huang, Z. C., Wang, P., Xu, M. J., Wang, L. S., Ding, Z. F., Wu, Y., Xu, M. J., Mi, N., Yu, D. Y., and Li, H.: Mantle structure and dynamics beneath SE Tibet revealed by new seismic images, Earth Planet. Sc. Lett., 411, 100-111, 2015.

Jiang, G. M., Zhao, D. P., and Zhang, G. B.: Crustal correction in teleseismic tomography and its application, Chinese J. Geophys., 52, 1508-1514, 2009.

Jiang, G. M., Zhang, G. B., Zhao, D., Lü, Q. T., Li, H. Y., and Li, X. F.: Mantle dynamics and Cretaceous magmatism in eastcentral China: Insight from teleseismic tomograms, Tectonophysics, 664, 256-268, 2015.

Karato, S.: Water distribution across the mantle transition zone and its implications for global material circulation, Earth Planet. Sc. Lett., 301, 413-423, 2011.

Kennett, B. and Engdahl, E.: Traveltimes for global earthquake location and phase identification, Geophys. J. Int., 105, 429-465, 1991.

Kawai, K., Yamammoto, S., Tsuchiya, T., and Maruyama, S.: The second continent: Existence of granitic continental materials around the bottom of the mantle transition zone, Geoscience Frontiers, 4, 1-6, 2013.

Kuritani, T., Ohtani, E., and Kimura, J. I.: Intensive hydration of the mantle transition zone beneath China caused by ancient slab stagnation, Nat. Geosci., 4, 713-716, 2011.

Laske, G., Masters, G., Ma, Z., and Pasyanos, M. E.: CRUST1.0: an updated global model of Earth's Crust, Geophys. Res. Abstr., 14, EGU2012-3743L, 2012.

Lei, J., Li, Y., Xie, F., Teng, J., Zhang, G., Sun, C., and Zha, $\mathrm{X}$.: Pn anisotropic tomography and dynamics under eastern
Tibetan plateau, J. Geophys. Res.-Sol. Ea., 119, 2174-2198, https://doi.org/10.1002/2013JB010847, 2014.

Li, C., van der Hilst, R. D., and Toksöz, M. N.: Constraining P-wave velocity variations in the upper mantle beneath Southeast Asia, Phys. Earth Planet. In., 154, 180-195, 2006.

Li, H. Y., Su, W., Wang, C. Y., and Huang, Z. X.: Ambient noise Rayleigh wave tomography in western Sichuan and eastern Tibet, Earth Planet. Sc. Lett., 282, 201-211, 2009.

Li, H. Y., Su, W., Wang, C. Y., Huang, Z. X., and Lv, Z. Y.: Ambient noise Love wave tomography in the eastern margin of the Tibetan plateau, Tectonophysics, 491, 194-204, 2010.

Li, X. H., Li, Z. X., Zhou, H., Liu, Y., and Kinny, P. D.: U-Pb zircon geochronology, geochemistry and $\mathrm{Nd}$ isotopic study of Neoproterozoic bimodal volcanic rocks in the Kangdian rift of South China: implications for the initial rifting of Rodinia, Precambrian Research, 113, 135-154, 2002.

Li, Z., Li, X., Zhou, H., and Kinny, P. D.: Grenvillian continental collision in south China: new SHRIMP U-Pb zircon results and implications for the configuration of Rodinia, Geology, 30, 163166, 2002.

Li, Z. W., Ni, S. D., and Roecker, S.: Interstation $P g$ and $S g$ differential traveltime tomography in the northeastern margin of the Tibetan plateau: Implications for spatial extent of crustal flow and segmentation of the Longmenshan fault zone, Phys. Earth Planet. In., 227, 30-40, 2014.

Lü, Y., Zhang, Z. J., Pei, S. P., Sandvol, E., Xu, T., and Liang, X. F.: 2.5-Dimensional tomography of uppermost mantle beneath Sichuan-Yunnan and surrounding regions, Tectonophysics, 627, 193-204, 2014.

Lustrino, M.: How the delamination and detachment of lower crust can influence basaltic magmatism, Earth-Sci. Rev., 72, 21-38, 2005.

Morgan, W. J.: Convection plumes in the lower mantle, Nature, 230, 42-43, 1971.

Paige, C. and Saunders, M.: LSQR: An algorithm for sparse linear equations and sparse least squares, Trans. Math. Software, 8, 4371, https://doi.org/10.1145/355984.355989, 1982.

Pirajno, F.: Ancient to Modern Earth: The Role of Mantle Plumes in the Making of Continental Crust, in: Earth's Oldest Rocks, Developments in Precambrian Geology, Vol. 15, edited by: van Kranendonk, M. J., Smithies, R. H., and Bennett, V. C., 1037-1064, 2007.

Pirajno, F. and Hoatson, D. M.: A review of Australia's Large Igneous Provinces and associated mineral systems: Implications for mantle dynamics through geological time, Ore Geol. Rev., 48, 2-54, 2012.

Rawlinson, N. and Spakman, W.: On the use of sensitivity tests in seismic tomography, Geophys. J. Int., 205, 1221-1243, https://doi.org/10.1093/gji/ggw084, 2016.

Safonova, I. Y. and Santosh, M.: Accretionary complexes in the Asia-Pacific region: Tracing archives of ocean plate stratigraphy and tracking mantle plumes, Gondwana Res., 25, 126-158, 2014.

Schmandt, B., Jacobsen, S. D., Becker, T. W., Liu, Z., and Dueker, K. G.: Dehydration melting at the top of the lower mantle, Science, 344, 1265-1268, 2014.

Shellnutt, J. G. and Iizuka, Y.: Oxidation zonation within the Emeishan large igneous province: Evidence from mantlederived syenitic plutons, J. Asian Earth Sci., 54, 31-40, https://doi.org/10.1016/j.jseaes.2012.03.011, 2012. 
Song, X. Y., Zhou, M. F., Cao, Z. M., and Robinson, P. T.: Late Permian rifting of the South China Craton caused by the Emeishan mantle plume?, J. Geol. Soc. London, 161, 773-781, 2004.

Song, H. J. Wignall, P. B., Tong, J. N., and Yin, H. F.: Two pulses of extinction during the Permian-Triassic crisis, Nat. Geosci., 6, 52-56, 2013.

Sun, S. S., Ji, S. C., Wang, Q., Wang, H. C. Long, C. X., and Salisbury, M.: Seismic properties of the Longmen Shan complex: Implications for the moment magnitude of the great 2008 Wenchuan earthquake in China, Tectonophysics 564, 68-82, https://doi.org/10.1016/j.tecto.2012.06.018, 2012.

Svenningsen, L., Balling, N., Jacobsen, B. H., Kind, R., Wylegalla, K., and Schweitzer, J.: Crustal root beneath the highlands of southern Norway resolved by teleseismic receiver functions. Geophys. J. Int., 170, 1129-1138, 2007.

Uenzelmann-Neben, G.: Volcanology: Magma giant, Nat. Geosci., 6, 902-903, 2013.

Ukstins Peate, I. and Bryan, S. E.: Re-evaluating plume-induced uplift in the Emeishan large igneous province, Nat. Geosci., 1, 625-629, 2008

Usuki, T., Lan, C. Y., Hoa, T. T., Dung, P. T., Wang, K. L., Shellnutt, J. G., and Chung, S. L.: Zircon U-Pb ages and Hf isotopic compositions of alkaline silicic magmatic rocks in the Phan Si Pan-Tu Le region, northern Vietnam: identification of a displacement western extension of the Emeishan large igneous province, J. Asian Earth Sci., 97, 102-124, 2015.

van Thienen, P., van den Berg, A. P., and Vlaar, N. J.: Production and recycling of oceanic crust in the early Earth, Tectonophysics, 386, 41-65, 2004.

Vlaar, N. J., van Keken, P. E., and van den Berg, A. P.: Cooling of the Earth in the Archaean: consequences of pressure-release melting in a hotter mantle, Earth Planet. Sc. Lett., 121, 1-18, 1994.

White, W. M.: Oceanic island basalts and mantle plumes: the geochemical perspective, Annu. Rev. Earth Pl. Sc., 38, 133-160, 2010.

Wignall, P. B.: Lethal volcanism, Nature, 477, 285-286, 2011.

Wilson, J. T.: A possible origin of the Hawaiian Islands, Can. J. Phys., 41, 863-870, 1963.

Xiao, L., Xu, Y. G., Mei, H. J., Zheng, Y. F., He, B., and Pirajno, F.: Distinct mantle sources of low-Ti and high-Ti basalts from the western Emeishan large igneous province, SW China: implications for plume-lithosphere interaction, Earth Planet. Sc. Lett., 228, 525-546, 2004.
Xu, Y. G., Chung, S. L., Jahn, B. M., and Wu, G. Y.: Petrologic and geochemical constraints on the petrogenesis of Permian-Triassic Emeishan flood basalts in Southwestern China, Lithos, 58, 145$168,2001$.

Xu, Y. G., He, B., Chung, S. L., Menzies, M., and Frey, F. A.: Geologic, geochemical, and geophysical consequences of plume involvement in the Emeishan flood-basalt province, Geology, 32, 917-920, 2004.

Xu, L. L., Rondenay, S., and van der Hilst, R. D.: Structure of the crust beneath the southeastern Tibetan Plateau from teleseismic receiver functions, Phys. Earth Planet. In., 165, 176-193, 2007.

Xu, Y., Yang, X. T., Li, Z. W., and Liu, J. H.: Seismic structure of the Tengchong volcanic area southwest China from local earthquake tomography, J. Volcanol. Geoth. Res., 239, 83-91, https://doi.org/10.1016/j.jvolgeores.2012.06.017, 2012.

Yang, T., Wu, J. P., and Wang, W. L.: Complex Structure beneath the Southeastern Tibetan Plateau from Teleseismic P-Wave Tomography, B. Seismol. Soc. Am., 104, 1056-1069, 2014.

Zhai, M. G., Fan, Q. C., Zhang, H. F., Sui, J. L., and Shao, J. A.: Lower crustal processes leading to Mesozoic lithospheric thinning beneath eastern North China: Underplating, replacement and delamination, Lithos, 96, 36-54, 2007.

Zhao, D.: Global tomographic images of mantle plumes and subducting slabs: Insight into deep Earth dynamics, Phys. Earth Planet. In., 146, 3-34, 2004.

Zhao, D., Hasegawa, A., and Horiuchi, S.: Tomographic imaging of $\mathrm{P}$ and $\mathrm{S}$ wave velocity structure beneath northeastern Japan, J. Geophys. Res.-Sol. Ea., 97, 19909-19928, https://doi.org/10.1029/92JB00603, 1992.

Zhao, D. P., Hasegawa, A., Kanamori, H.: Deep structure of Japan subduction zone as derived from local, regional and teleseismic events, J. Geophys. Res.-Sol. Ea., 99, 22313-22329, https://doi.org/10.1029/94JB01149, 1994.

Zhao, L., Paul, A., Malusà, M. G., Xu, X. B., Zheng, T. Y., Solarino, S., Guillot, S., Schwartz, S., Dumont, T., Salimbeni, S., Aubert, C., Pondrelli, S., Wang, Q. C., and Zhu, R. X.: Continuity of the Alpine slab unraveled by high-resolution $\mathrm{P}$ wave tomography, J. Geophys. Res.-Sol. Ea., 121, 8720-8737, 2016.

Zheng, X. F., Yao, Z. X., Liang, J. H., and Zheng, J.: The Role Played and Opportunities Provided by IGP DMC of China National Seismic Network in Wenchuan earthquake disaster relief and researches, B. Seismol. Soc. Am., 100, 2866-2872, 2010.

Zheng, Y. F., Xiao, W. J., and Zhao, G. C.: Introduction to tectonics of China, Gondwana Res., 23, 1189-1206, 2013. 